\title{
USING LMS DATA TO UNDERSTAND HOW STUDENTS USE COURSE TOOLS
}

\author{
Queen E. Booker, Minnesota State University, Mankato, queen.booker@mnsu.edu \\ Carl M. Rebman Jr., University of San Diego, carlr@sandiego.edu
}

\begin{abstract}
Despite the potential wealth of educational indicators expressed in a student's approach to completing writing exercises, the specific tools a student uses to develop their first submission is largely overlooked in online university courses. In this paper we present a methodology to analyze student behavior in developing their writing skills using LMS data and how that use impacts the design of the course. This paper examines the tools and resources provided to students to learn effective business communications The purpose was to demonstrate that instructors can learn about student behaviors and learning design on student success for a particular outcome. The analysis performed supports the belief that LMS data can potentially be used to improve course design.
\end{abstract}

Keywords: Learning Design, Learning Analytics, Performance, Retention, Experimentation, Design, Measurement

\section{INTRODUCTION}

The ability to communicate effectively is a critical skill for obtaining and maintaining a successful career. Yet, many students are deficient in these skills despite university resources that are dedicated to writing in general. Graduates particularly lack adequate writing skills. When courses are taught using online learning management systems (LMS), a wealth of information is generated that can help us understand what tools students use, when they use them, and for how long. This information can help teachers understand the development path the students took to produce the final product. It can also help an instructor to know whether or not students elect to simply ignore the material related to writing, which could indicate that the lack of learning may not be the course design but the student's individual choice.

In traditional settings, the data on how students develop their papers over time is generally not available unless a specific campus area such as the writing center or library keeps track of which student comes in for assistance and how often. In this study, we analyze data from an online environment and show that traces of the development paths taken by students in low level general business course can be mined to build models that capture common major milestones in such development paths.

Understanding the tools that best prepare students to improve their business writing can help instructors better identify not only the best tools for students but also which students actually need interventions. This is particularly helpful as class size increases. Using data from an LMS can help with both of these processes without having to ask students if they visited the library, the graduate assistant or the writing center. Conversely, using the LMS to track student behaviors does not require the instructor to ask the centers to violate student privacy. An automated approach using data from the LMS can be applied as students click and use information can be observed through the activity logs for each student. Using this data can identify key situations or development paths that have led to successful submissions.

Learning analytics can provide instructor with tools and opportunities to support student progression and to enable personalized learning (Siemens, Dawson, and Lynch, 2013, Tobarra, Robles-Gómez, Ros, Hernández, Caminero, 2014, Tempelaar, Rienties, and Giesbers, 2015). With the increased availability of large datasets and analytics engines (Tobarra, Robles-Gómez, Ros, Hernández, Caminero, 2014), instructors can to use past experience to create supportive, insightful models of primary (and perhaps real-time) learning processes (Verbert, Duval, Klerkx, Govaerts, Santos, 2013). While substantial progress has been made in terms of predictive modeling in the Learning 
Analytics Knowledge (LAK) community over the last three to four years ((Tobarra, Robles-Gómez, Ros, Hernández, Caminero, 2014)), one element that seems to need more attention is learning design.

Learning design is the process instructors use to design a course to maximize student learning. Instructors engage a variety of tools and resources such as books, articles, activities, and technologies. (Conole 2012, Cross, Gallery, Brasher, and Weller, 2012). A learning management system (LMS) is one technology many instructors now use as part of the course design. The LMS can contain reading material, exercises and quizzes for the students to access anytime and anywhere. The data captured by an LMS can help an instructor determine whether a particular tool or resource contributes to student performance and learning success. This study examines how LMS data elements may be used to enhance course design.

Although there has been significant research on modeling student behaviors in the online environment, only one study has been found that focus on using learning analytics for learning design. In their study, Rienties et al (2015) suggests that combining information on learning outcomes with data on design and student use of the tools used in the design can help determine best practices for individual students as well as improve the course. They also state that a particularly useful feature would be to integrate the design data with individual data about students to determine what may influence a student's ability to learn, and whether a learning design is suitable for a range of learners. This is because learning design choices made by teachers definitely influence subsequent learning processes and learning performance over time.

For this study, we focus on a single online learning module of an online only course. We examine the tools and resources provided to students to learn effective business communications. The patterns found helped to explain which tools were being consulted during the writing process and when, and how effective the student was able to use the tool. We were also able to identify, by using LMS and other modules' data, whether or not students simply did not start or complete the writing exercises.

The main result presented in this paper is an approach to analyzing a module design to determine if the activities provided are value added to the student's learning process.

\section{RESEARCH METHODOLOGY}

This study took place at Minnesota State Mankato (MSM), a regional comprehensive university in the United States. The study focused on a specific college level learning outcome, that students can demonstrate competency in written business communications. The micro learning outcomes involve context and purpose for writing, content development, and control of syntax and mechanics. Using a modified AAUP Writing Rubric for measuring progress, students were expected to have low level skills in context and purpose for writing, content development and high level skills in control of syntax and mechanics.

We gathered and analyzed the data for students enrolled in Principle of Management (POM) course, which begins with a requirement that students complete a business communications tools module and an initial short (between 500-750 words) writing exercise during the first two weeks of the semester. The business communication tools module and exercise were followed by four additional short writing exercises spread across the semester. 
The module was designed using a combination of principles of quality design from Quality Matters (C) and the Online Learning Consortium (OLC) $\mathbb{C}$. The learning activities were mapped and reviewed by a team of learning designers from MSM and consultants from OLC. The team reviewed the learning materials, classified the types of activity, and quantifies the time that students were expected to spend on each activity. To minimize subjectivity, individuals examined and classified independently and then ratings were discussed to ensure consistency in design expectations. Once the mapping process was complete, the OLC consultant reviewed the module with the instructor to improve the module design. The final module design included a combination of grammar quizzes, colloquial language versus business language quizzes, reading material, videos lectures on effective writing, and examples of exemplary written business communications.

The module itself has one assignment but the course has four additional assignments to continually measure writing improvements. The data collected for the study included the total number of visits to the module content; and average time spent on a particular topic. This includes whether or not a student returned to the module when new writing exercises were introduced in later modules. The data was collected for six (6) semesters. Because we focused on one specific learning outcome in one specific online course, we were able to examine individual and micro learning analytics tracking data such as types of content, materials and ICT tools (e.g., wikis, videoconference, discussion forums) accessed and when.

Learning performance was by individual, and calculated by the rubric scoring on the three areas of the micro learning outcome. Retention was measured in terms of whether or not the student completed subsequent writing exercises in the course as not all students completed all the writing exercises.

\section{Data Collection}

For the past three years, the Principles of Management class has been taught $100 \%$ online in primarily in one section with enrollments ranging from 242 to 264 students per semester. This course is a typical junior level business core course requirement for business majors and minors, and a course in which written business communications is a primary learning outcome. Students are expected to know grammar and punctuation, and to learn to the business context of and purpose for writing, and business content development.

The students had access to eleven (11) different types of learning activities. Table 1 repeats Reinties, et. al (2015) list of Learning Design Activities.

Table 1. Learning Design Activities

\begin{tabular}{|l|l|l|}
\hline & \multicolumn{1}{|c|}{ Type of Activity } & \multicolumn{1}{c|}{ Example } \\
\hline Assimilative & Attending to information & $\begin{array}{l}\text { Read, Watch, Listen, Think about, } \\
\text { Access }\end{array}$ \\
\hline $\begin{array}{l}\text { Finding and handling } \\
\text { information }\end{array}$ & $\begin{array}{l}\text { Searching for and processing } \\
\text { information }\end{array}$ & $\begin{array}{l}\text { List, Analyze, Collate, Plot, Find, } \\
\text { Discover, Access, Use, Gather }\end{array}$ \\
\hline Communication & $\begin{array}{l}\text { Discussing module } \\
\text { Related content with at least one } \\
\text { person (student or tutor) }\end{array}$ & $\begin{array}{l}\text { Communicate, Debate, Discuss, } \\
\text { Argue, Share, Report, Collaborate, } \\
\text { Present, Describe }\end{array}$ \\
\hline Productive & $\begin{array}{l}\text { Actively constructing } \\
\text { an artifact }\end{array}$ & $\begin{array}{l}\text { Create, Build, Make, Design, } \\
\text { Construct, Contribute, Complete }\end{array}$ \\
\hline Experiential & $\begin{array}{l}\text { Applying learning in a } \\
\text { real-world setting }\end{array}$ & $\begin{array}{l}\text { Practice, Apply, Mimic, } \\
\text { Experience, Explore, Investigate }\end{array}$ \\
\hline $\begin{array}{l}\text { Interactive/ } \\
\text { Adaptive }\end{array}$ & $\begin{array}{l}\text { Applying learning in a } \\
\text { simulated setting }\end{array}$ & $\begin{array}{l}\text { Explore, Experiment, Trial, } \\
\text { Improve, Model, Simulate }\end{array}$ \\
\hline Assessment & $\begin{array}{l}\text { All forms of assessment } \\
\text { (summative, formative, } \\
\text { and self-assessment) }\end{array}$ & $\begin{array}{l}\text { Write, Present, Report } \\
\text { Demonstrate, Critique }\end{array}$ \\
\hline
\end{tabular}

Each of the activities used in the module were coded by the learning design team. The business communications learning activities and their assigned type include the following: 
- Lynda.com: Business Writing Fundamentals (Assimilative)

- MSU Library: Library Guide: Business Writing Resources (Assimilative)

- Effective Communications PowerPoint Guide (Assimilative)

- Article: http://grammar.about.com/od/ab/g/businesswritingterm.htm (Assimilative)

- Article: https://owl.english.purdue.edu/owl/section/4/16/_(Assimilative)

- Sample exercise with solutions (Interactive)

- Discussion Forums (Communications)

- Grammar Quizzes (Interactive)

- Business Language Quizzes (Assessment)

- Review of/correction of/assessment of memos (Assessment)

- Rewriting of an existing memo (Experiential)

Inside the LMS, the learning activities are encoded as direct links inside the course rather than as external links. Doing so allows the system to capture when the student opens an activity, providing date, time, and length of time the tool remained active. The system also captures when the student opens the actual exercise for the first time and when the final exercise is submitted as well as detects if and when a student re-opens the exercise and makes changes.

To transition students from general communications to business communications, specifically, short internal memorandums, the course design requires five (5) small writing assignments with an expected response of between 500 and 750 words. The first assignment provides specific prompts and requires minimal critical thinking so that the student focuses primarily on context and content skills development. Subsequent assignments provide fewer prompts and higher order critical thinking. All of the assignments are graded on three learning outcomes using a modified AAUP Writing Rubric. The number of students enrolled each semester is shown in Table 2: Student Enrollment.

Table 2. Student Enrollment

\begin{tabular}{|c|c|c|}
\hline $\begin{array}{c}\text { Academic } \\
\text { Year }\end{array}$ & Fall & Spring \\
\hline $2012-2013$ & 264 & 253 \\
\hline $2013-2014$ & 255 & 257 \\
\hline $2014-2015$ & 242 & 245 \\
\hline
\end{tabular}

Grading of the assignments by rubric was automated for Fall 2012 by having three (3) instructors evaluate 100 student submissions from the Spring 2012. The instructors identified common colloquial phrases, poor sentence structures, and typically misused words (e.g., their versus there). A text ontology was created from the papers to read and grade the exercises based on the rubric. The system was trained on the same 100 submissions and tested on an additional 30 to validate, refine, and revalidate before using in Fall 2012. This paper processing system was validated at the beginning of each semester by testing a random sample of $10 \%$ of the first submitted assignment to ensure the text processing grading system works.

In addition to having the rubric grade for each of the competencies for each paper submitted, we were also able to capture which learning activities the students used, and when they used them.

\section{Data Analysis}

For this study, we were interested in four outcomes:

1. How many students started and completed all five writing assignments (learning outcome retention)?

2. Which tools did the students used and when (activity use and retention)?

3. Whether or not students achieved the desired level of competency for the three rubric areas and if so, which tools appear to be most effective (learning design)

4. What was the impact of the selected learning activities on achieving the respective level of competencies? 


\section{Learning Outcome Retention}

Table 3 shows the number of students who started the respective number of assignments. On average, $78 \%$ of the class started all five assignments, where started was defined as clicking and opening the assignment and typing something into the assignment learning submission. It is important to note that students starting one (1) or more assignments did not necessarily complete them sequentially. For example, a student might have started assignment 3 but never looked at assignments 1 and 2 .

Table 3. Number of Students Starting Assignments

\begin{tabular}{|c|c|c|c|c|c|c|c|c|}
\hline \multirow{2}{*}{$\begin{array}{c}\text { Academic } \\
\text { Year }\end{array}$} & \multirow{2}{*}{ Enrollment } & \multicolumn{6}{|c|}{$\begin{array}{c}\text { Number of Assignments } \\
\text { Started }\end{array}$} & \multirow{2}{*}{$\begin{array}{c}\text { Percent } \\
\text { Starting }\end{array}$} \\
\cline { 3 - 9 } & & $\mathbf{5}$ & $\mathbf{4}$ & $\mathbf{3}$ & $\mathbf{2}$ & $\mathbf{1}$ & $\mathbf{0}$ & \\
\hline Fall 2012 & 264 & 204 & 32 & 7 & 9 & 7 & 5 & $77 \%$ \\
\hline Spring 2013 & 253 & 195 & 30 & 7 & 10 & 4 & 7 & $77 \%$ \\
\hline Fall 2013 & 255 & 196 & 30 & 8 & 8 & 9 & 4 & $77 \%$ \\
\hline Spring 2014 & 257 & 203 & 21 & 9 & 8 & 7 & 9 & $79 \%$ \\
\hline Fall 2014 & 242 & 188 & 30 & 4 & 5 & 6 & 9 & $78 \%$ \\
\hline Spring 2015 & 245 & 194 & 27 & 4 & 3 & 9 & 8 & $79 \%$ \\
\hline
\end{tabular}

Table 4 shows the number of students who completed the respective number of assignments. On average, $72 \%$ of the class completed all five assignments, where completed is defined as submitting an assignment for grading. Although the retention to the writing improved by $1 \%$ in future semesters, the difference in completion was not significantly different from semester to semester.

Table 4. Number of Students Completing Assignments

\begin{tabular}{|c|c|c|c|c|c|c|c|c|}
\hline \multirow{2}{*}{$\begin{array}{c}\text { Academic } \\
\text { Year }\end{array}$} & \multirow{2}{*}{ Enrollment } & \multicolumn{6}{|c|}{$\begin{array}{c}\text { Number of Assignments } \\
\text { Completed }\end{array}$} & \multirow{2}{*}{$\begin{array}{c}\text { Percent } \\
\text { Completing }\end{array}$} \\
\cline { 3 - 9 } & & $\mathbf{5}$ & $\mathbf{4}$ & $\mathbf{3}$ & $\mathbf{2}$ & $\mathbf{1}$ & $\mathbf{0}$ & \\
\hline Fall 2012 & 264 & 187 & 37 & 9 & 13 & 11 & 7 & $71 \%$ \\
\hline $\begin{array}{c}\text { Spring } \\
2013\end{array}$ & 253 & 180 & 34 & 12 & 11 & 8 & 8 & $71 \%$ \\
\hline Fall 2013 & 255 & 180 & 36 & 11 & 8 & 9 & 11 & $71 \%$ \\
\hline $\begin{array}{c}\text { Spring } \\
2014\end{array}$ & 257 & 186 & 21 & 14 & 11 & 14 & 11 & $72 \%$ \\
\hline Fall 2014 & 242 & 175 & 33 & 5 & 9 & 8 & 12 & $72 \%$ \\
\hline $\begin{array}{c}\text { Spring } \\
2015\end{array}$ & 245 & 176 & 32 & 11 & 8 & 10 & 8 & $72 \%$ \\
\hline
\end{tabular}

\section{Tools Students Used}

Our next analysis was to determine which tools students used and when. We analyzed the data by looking at which activities were used before the assignment was opened, while the assignment was open, and after the student received their grades. Although we analyzed the data for each semester, we are only reporting aggregate percent information on the most used activities. Table 5 shows the aggregate use. The most commonly used activity before opening an exercise was the business language quiz followed by the discussion forum. During the exercise, the students used the discussion forum the most, and afterwards, the business language quizzes again. Only the review/correction activities were used less than $50 \%$ at any time. 
Table 5. Activity Usage

\begin{tabular}{|l|c|c|c|}
\hline \multicolumn{1}{|c|}{ Learning Activity } & Before & During & After \\
\hline Lynda.com: Business Writing Fundamentals (Assimilative) & $62 \%$ & $75 \%$ & $67 \%$ \\
\hline $\begin{array}{l}\text { MSU Library: Library Guide: Business Writing Resources } \\
\text { (Assimilative) }\end{array}$ & $60 \%$ & $66 \%$ & $77 \%$ \\
\hline $\begin{array}{l}\text { Effective Communications PowerPoint Guide } \\
\text { (Assimilative) }\end{array}$ & $57 \%$ & $59 \%$ & $57 \%$ \\
\hline $\begin{array}{l}\text { Article: } \\
\text { http://grammar.about.com/od/ab/g/businesswritingterm.htm } \\
\text { (Assimilative) }\end{array}$ & $59 \%$ & $73 \%$ & $52 \%$ \\
\hline $\begin{array}{l}\text { Article: https://owl.english.purdue.edu/owl/section/4/16/ } \\
\text { (Assimilative) }\end{array}$ & $69 \%$ & $73 \%$ & $68 \%$ \\
\hline Sample exercise with solutions (Interactive) & $70 \%$ & $72 \%$ & $75 \%$ \\
\hline Discussion Forums (Communications) & $79 \%$ & $89 \%$ & $80 \%$ \\
\hline Grammar Quizzes (Interactive) & $72 \%$ & $74 \%$ & $81 \%$ \\
\hline Business Language Quizzes (Interactive) & $86 \%$ & $83 \%$ & $86 \%$ \\
\hline $\begin{array}{l}\text { Review of/correction of/assessment of memos } \\
\text { (Assessment) }\end{array}$ & $41 \%$ & $45 \%$ & $43 \%$ \\
\hline Rewriting of an existing memo (Experiential) & $55 \%$ & $59 \%$ & $60 \%$ \\
\hline
\end{tabular}

Next, we analyzed tools skill improvement followed by retention and rubric scores, and tools used correlated to score on the three rubric competencies as the learning design analysis.

\section{Skills Improvement}

As instructors, it is important to know if the student improves with more assignments (repeated exposure) or not, and if those changes were significant. For this analysis we considered student performance on subsequent assignments. For this analysis, we extracted the rubric grades from the LMS for each student for each assignment completed. Recall the three rubric competencies: context of and purpose for writing, content development, and control of syntax and mechanics. The rubric competencies are score on a scale of 0 to 5 where 0 is student did not meet the minimum criteria and 5 was the student surpassed the expectation. The learning outcome goal for the course was for all students to achieve 4 or higher for context and content, and 5 for syntax and mechanics. The average results across all semesters are shown in Table 6. The table reports the averages across all semesters. Additional quizzes for the grammar were added for the last three semesters so there is a significant improvement in the last three semesters where the grammar grades improved from approximately 1.3 in Fall 2012 to 4.4 in the Spring 2015. It is important to also note that the variance was significant in the differences between semesters as well as in the assignment grades themselves.

Table 6. Average Rubric Score for Each Assignment

\begin{tabular}{|l|r|r|r|r|r|}
\hline \multirow{2}{*}{ Competency } & \multicolumn{5}{|c|}{\begin{tabular}{c} 
Average Rubric Score for Each Writing \\
\cline { 2 - 6 }
\end{tabular}} \\
\cline { 2 - 6 } & $\mathbf{1}$ & $\mathbf{2}$ & $\mathbf{3}$ & $\mathbf{4}$ & $\mathbf{5}$ \\
\hline $\begin{array}{l}\text { context of and } \\
\text { purpose for writing }\end{array}$ & 1.5 & 2.0 & 2.7 & 3.1 & 4.2 \\
\hline content development & 1.9 & 2.2 & 2.4 & 3.2 & 4.4 \\
\hline $\begin{array}{l}\text { control of syntax and } \\
\text { mechanics }\end{array}$ & 2.0 & 2.3 & 2.6 & 2.6 & 3.8 \\
\hline
\end{tabular}




\section{Learning Design Impact}

The final analysis of interest was if the selected assignment had an impact. To conduct this analysis, we performed a correlation analysis of the assignment score and if the student used it before or during the completion of the assignment. If a student opened the activity AFTER the completion of another assignment, it was considered used before the next assignment. We ran a correlation analysis and found that specific activities were significantly positively and negatively correlated to the score on each rubric competency. The correlation table for the rubric score for each of the three competencies are shown in Tables 7-9, specifically context of and purpose for writing is shown in Table 7, for content development, Table 8, and for control of syntax and mechanics, Table 9.

Table 7. Context and Purpose

\begin{tabular}{|l|c|c|}
\hline \multicolumn{1}{|c|}{ Activity } & $\begin{array}{l}\text { Pearson } \\
\text { Correlation }\end{array}$ & Sig. (2-tailed) \\
\hline Lynda.com: Business Writing Fundamentals (Assimilative) & $.186^{* *}$ & 0.000 \\
\hline $\begin{array}{l}\text { MSU Library: Library Guide: Business Writing Resources } \\
\text { (Assimilative) }\end{array}$ & 0.006 & 0.821 \\
\hline $\begin{array}{l}\text { Effective Communications PowerPoint Guide } \\
\text { (Assimilative) }\end{array}$ & 0.01 & 0.709 \\
\hline $\begin{array}{l}\text { Article: } \\
\text { http://grammar.about.com/od/ab/g/businesswritingterm.htm } \\
\text { (Assimilative) }\end{array}$ & $.178^{* *}$ & 0.000 \\
\hline $\begin{array}{l}\text { Article: https://owl.english.purdue.edu/owl/section/4/16/ } \\
\text { (Assimilative) }\end{array}$ & $.222^{* *}$ & 0.000 \\
\hline Sample exercise with solutions (Interactive) & 0.01 & 0.702 \\
\hline Discussion Forums (Communications) & $.070^{* *}$ & 0.007 \\
\hline Grammar Quizzes (Interactive) & $.191^{* *}$ & 0.000 \\
\hline Business Language Quizzes (Assessment) & $.168^{* *}$ & 0.000 \\
\hline $\begin{array}{l}\text { Review of/correction of/assessment of memos } \\
\text { (Assessment) }\end{array}$ & $.146^{* *}$ & 0.000 \\
\hline Rewriting of an existing memo (Experiential) & $.146^{* *}$ & 0.000 \\
\hline
\end{tabular}

Table 8. Content Development

\begin{tabular}{|l|c|c|}
\hline \multicolumn{1}{|c|}{ Activity } & $\begin{array}{l}\text { Pearson } \\
\text { Correlation }\end{array}$ & Sig. (2-tailed) \\
\hline Lynda.com: Business Writing Fundamentals (Assimilative) & $.193^{* *}$ & 0.000 \\
\hline $\begin{array}{l}\text { MSU Library: Library Guide: Business Writing Resources } \\
\text { (Assimilative) }\end{array}$ & 0.003 & 0.821 \\
\hline $\begin{array}{l}\text { Effective Communications PowerPoint Guide } \\
\text { (Assimilative) }\end{array}$ & 0.01 & 0.709 \\
\hline $\begin{array}{l}\text { Article: } \\
\text { http://grammar.about.com/od/ab/g/businesswritingterm.htm } \\
\text { (Assimilative) }\end{array}$ & $.188^{* *}$ & 0.000 \\
\hline $\begin{array}{l}\text { Article: https://owl.english.purdue.edu/owl/section/4/16/ } \\
\text { (Assimilative) }\end{array}$ & $.222^{* *}$ & 0.000 \\
\hline Sample exercise with solutions (Interactive) & 0.05 & 0.702 \\
\hline Discussion Forums (Communications) & $.081^{* *}$ & 0.007 \\
\hline Grammar Quizzes (Interactive) & $.191^{* *}$ & 0.000 \\
\hline Business Language Quizzes (Assessment) & $.178^{* *}$ & 0.000 \\
\hline $\begin{array}{l}\text { Review of/correction of/assessment of memos } \\
\text { (Assessment) }\end{array}$ & $.155^{* *}$ & 0.000 \\
\hline Rewriting of an existing memo (Experiential) & $.146^{* *}$ & 0.000 \\
\hline
\end{tabular}


Table 9. Correlation Table for Control of Syntax and Mechanics

\begin{tabular}{|l|c|c|}
\hline \multicolumn{1}{|c|}{ Activity } & $\begin{array}{c}\text { Pearson } \\
\text { Corr. }\end{array}$ & Sig. (2-tailed) \\
\hline Lynda.com: Business Writing Fundamentals (Assimilative) & $.188^{* *}$ & 0.000 \\
\hline $\begin{array}{l}\text { MSU Library: Library Guide: Business Writing Resources } \\
\text { (Assimilative) }\end{array}$ & 0.01 & 0.698 \\
\hline $\begin{array}{l}\text { Effective Communications PowerPoint Guide } \\
\text { (Assimilative) }\end{array}$ & 0.012 & 0.637 \\
\hline $\begin{array}{l}\text { Article: } \\
\text { http://grammar.about.com/od/ab/g/businesswritingterm.htm } \\
\text { (Assimilative) }\end{array}$ & $.182^{* *}$ & 0.000 \\
\hline $\begin{array}{l}\text { Article: https://owl.english.purdue.edu/owl/section/4/16/ } \\
\text { (Assimilative) }\end{array}$ & $.220^{* *}$ & 0.000 \\
\hline Sample exercise with solutions (Interactive) & 0.006 & 0.820 \\
\hline Discussion Forums (Communications) & $-.067^{* *}$ & 0.009 \\
\hline Grammar Quizzes (Interactive) & $.198^{* *}$ & 0.000 \\
\hline Business Language Quizzes (Assessment) & $.175^{* *}$ & 0.000 \\
\hline $\begin{array}{l}\text { Review of/correction of/assessment of memos } \\
\text { (Assessment) }\end{array}$ & $.158^{* *}$ & 0.000 \\
\hline
\end{tabular}

All three results show support for all of the learning activities except the sample assignment, the PowerPoint guide, and the MSU Library resources. However, the discussion forum had a negative correlation to the grammar rubric score.

\section{RESULTS}

This study presented an approach to using LMS data to analyze the learning design for specific learning outcome, combining module use data with student performance to determine if the design is useful. The study used repeated semesters to increase reliability of the results. The preliminary results suggest that overall the module design is useful in helping students achieve the desired learning outcomes. Further research is necessary, though, to ensure that the achievements are consistent across demographics. The study indicated specific tools that may not be useful to the actual learning process. However, the instructor should not simply eliminate the tools until further studies are performed on learning styles. These studies would help to determine if there is some relevance or correlation between learning style and tools used.

\section{CONCLUSIONS AND FUTURE WORK}

This was one study, on one module, in one class on one learning outcome. The purpose was to demonstrate that instructors can learn about student behaviors and learning design on student success for a particular outcome. This is particularly important for instructor as we will need ways of understanding what is happening within our courses as we continue to try to close the achievement gap in education. There is a substantial limitation of this study due to its narrow focus. For example, in this study the percentage of all assignments completed was an average of $72 \%$ (85\% when four out of five assignments were completed). This is not too surprising given that many students tend to avoid writing assignments, and it is one area this study did not address was the motivation, factors and reasons that students decide not to complete assignments. Again, this study was solely focused on one module in one class on one learning outcome. Further research studies could be helpful in providing some possible answers towards student motivation and performance. 
Still, the analysis performed supports the belief that LMS data can potentially be used to improve course design. Future studies will include tools in the actual modules were content was learned to determine if the content in those modules influenced the improvements on the non-grammar rubric competencies. Regression and cluster analyses, path determinations, and predictive models are also possible from the learning design. Lastly, to ensure that the design is not contributing to an achievement gap, demographics must be studied as well.

\section{REFERENCES}

Conole, G. (2012). Designing for learning in an open world (Vol. 4). Springer Science \& Business Media.

Cross, S., Galley, R., Brasher, A., \& Weller, M. (2012). Final Project Report of the OULDI-JISC Project: Practice, Challenge and Change in Curriculum Design Process, Communities, Visualisation and Practice. City.

Rienties, B., Toetenel, L., \& Bryan, A. (2015, March). Scaling up learning design: impact of learning design activities on LMS behavior and performance. In Proceedings of the Fifth International Conference on Learning Analytics And Knowledge, pp. 315-319. ACM.

Siemens, G., Dawson, S., \& Lynch, G. (2013). Improving the quality and productivity of the higher education sector. Policy and Strategy for Systems-Level Deployment of Learning Analytics. Canberra, Australia: Society for Learning Analytics Research for the Australian Office for Learning and Teaching.

Tempelaar, D. T., Rienties, B., \& Giesbers, B. (2015). In search for the most informative data for feedback generation: Learning Analytics in a data-rich context. Computers in Human Behavior, 47, 157-167.

Tobarra, L., Robles-Gómez, A., Ros, S., Hernández, R., \& Caminero, A. C. (2014). Analyzing the students' behavior and relevant topics in virtual learning communities. Computers in Human Behavior, 31, 659-669.

Verbert, K., Duval, E., Klerkx, J., Govaerts, S., \& Santos, J. L. (2013). Learning analytics dashboard applications. American Behavioral Scientist, 0002764213479363. 